\title{
Implementation of R.A.9184 in DPWH Region III in the Bidding of Infrastructure Projects
}

\author{
Vivian E. Gutierrez, Rex Mervin P. Ramos, Ryan John L. De Lara Noel T. Florencondia
}

\begin{abstract}
Compliance to Government Procurement Act R.A.9184 by procuring entities remains the biggest challenge to realize the objectives of equality, transparency and responsibility in government procurement in the country. The study focuses on assessing the existing implementation of R.A. 9184 in the bidding of infrastructure projects of concerned District Engineering Offices in Region III by considering the constraints on its processes. There were 45 respondents answered the questionnaires gathered from the seven (7) District Engineering offices of DPWH Region III, namely, Zambales, Bataan and Pampanga. Interviews and feedbacks from the Bids and Award Committee members (BAC), BAC secretariat and Technical Working Groups (TWG) of the Procurement Division of Infrastructure projects were conducted to substantiate the answers of the respondents. The data collected were treated statistically using percentage and weighted mean. All respondents show level of awareness and understanding in the implementation of R.A 9184 of bidding process and they are able to review and re-evaluated all concerns pertaining to any ambiguity of the process. Respondents show competence on how far they understand and implement the process properly. The researchers find that there is a need in identifying minor irregularities to major irregularities to eliminate confusion in selecting the lowest responsive bidder.
\end{abstract}

Keywords : Bidding, Engineering, Issues, Projects

\section{INTRODUCTION}

Public procurement in the Philippines shows relevant illustration of how much important of the implementation can matter. Transparency is very vital to the public oversight to encounter conditions of availability and usability. Government procurement in the Philippines is guided by the Government Procurement Reform Act (R.A. 9184) and its Implementing Rules and Regulations (IRR)[3]. This provides for a comprehensive government procurement reform

Revised Manuscript Received on December 30, 2019.

* Correspondence Author

Vivian E. Gutierrez*, Engineering Department, Columban College, Inc. Olongapo City, Zambales, Philippines,

Rex Mervin P. Ramos, Graduate School Department, Nueva Ecija University of Science and Technology, Cabanatuan City ,Philippines,

Ryan John L. De Lara, Research Development and Productivity Office, Wesleyan University Philippines, Cabanatuan City, Philippines,

Noel T. Florencondia, Graduate School Department, Nueva Ecija University of Science and Technology, Cabanatuan City, Philippines.

(C) The Authors. Published by Blue Eyes Intelligence Engineering and Sciences Publication (BEIESP). This is an open access article under the CC BY-NC-ND license (http://creativecommons.org/licenses/by-nc-nd/4.0/) program with electronic system component that serves as source of information for all government procurements Policies and practices are anchored on the pursuit of economy and efficiency while upholding integrity and transparency. The procurement process in all government agencies is standardized, including the forms used, and follows a generic procurement manual to avoid confusion and ensure transparency [3].

Despite the reforms in Government Procurement it still suffers from poor performance characterized by noncompliance with the Act, lack of policy on procurement, slow with a lot of bureaucracy, overspending, need for more transparency and accountability, eradication of wastage and corruption, addressing collusion in the tender evaluation and award, inadequate training of the procurement officers especially on the technical fields. These are some of the issues surrounding the inefficiencies in procurement function in the government entities [6].

\section{Statement of the Problem}

The researcher finds the necessity to assess the implementation of Republic Act 9184 in the bidding of infrastructure projects. The study will seek answering the following questions:

1. What is the current level of awareness and understanding of R.A. 9184?

2. What are the different challenges encountered by DPWH Region III concerned District Engineering Offices related to procurement of civil works based on R.A 9184?

3. What are the common problems, issues, and concern in the bidding of infrastructure projects in DPWH Region III District Engineering Offices?

4. How can the challenges, problems, issues and concern be resolved or mitigated?

\section{Objective of the Study}

The objective of this study is to determine procurement implementation of national government bidding system for infrastructure projects and identify the problems and issues face by the concerned District Engineering Offices of DPWH in Region III. 


\section{Scope and Limitation}

The scope of the research is limited to the issues and challenges in the implementation of government procurement in the bidding of infrastructure projects in DPWH Region III concerned District Engineering Offices. The study will limit its understanding to the Department of Public Works and Highway on the bidding process of infrastructure projects of the area specified. The knowledge and compliance in the implementation of R.A. 9184 in the bidding of infrastructures projects will also determine.

\section{REVIEW OF RELATED LITERATURE}

\section{Foreign}

As stated earlier by Kihara (2009), security contracts were exempted from the Regulations where the minister for Finance decided, in consultation with the head of the procuring entity, that it was in the interest of national security to use a different procedure[7]. This section gave a blank cheque to the minister resulting to scandals such as the Anglo leasing scandal where security was cited to justify procurement by single sourcing which resulted to overpricing of the procured items. This scandal involved Kshs.56.5 billion in the process of which the Government lost a lot of money in unclear procurement deals (GoK, 2001)[7].

In 2003, an independent procurement review of public procurement was undertaken which identified shortcomings such as, abuse of contract variations, poor record keeping for audit, lack of guidance on low value procurements, lengthy procurement process, conflict of interest, lack of evidence on procured items among many weaknesses (Odhiambo, 2005). This led to the dismissal of 2,000 procurement officers from ministries and state corporations in a bid to clean up the entire sector and workforce. Procurement activities were also temporally suspended [7].

The issue of generalizing that the procurement function is not performing without indicating the criteria used to reach that conclusion or just basing it on financial statements is not reasonable. Only when the procurement function is well planned, it is easy to identify areas where it is performing well, and where there is need for improvement (Department of Public Works, Queensland Government, 2007)[8].

Wanyama (2010) posits that the principle provisions of the Act and the Regulations have inherent weakness prone to abuses by procuring entities and do not envisage contemporary market realities. Kenyanya et al (2010), also argues that though development of mechanism for contract administration and appeals was hailed as a positive move, institutional capacity in procuring entities and procurement markets are the weakest[7]. However PPOA (2007) reveals that the strongest points of the reforms have been the delegation of the procurement decisions which have been fully achieved. The report adds that the responsibility of procurement have been fully left to the tender committees and units of the procuring entities[7].

\section{Local}

Public procurement in the Philippines is guided by the Government Procurement Reform Act (RA 9184) and its Implementing Rules and Regulations (IRR)[3]. This provides for a comprehensive government procurement reform program with electronic system component that serves as source of information for all government procurements e.g. issuances on specific procurement, bid opportunities, rules and regulations, press releases, directory of government agencies and contract thus making the entire process transparent and competitive. The procurement process in all government agencies is standardized, including the forms used, and follows a generic procurement manual to avoid confusion and ensure transparency [3]. Government agencies have respective Bids and Awards Committee (BAC) that conducts all procurement activities. The BAC is composed of regular members who are permanent officials of the procuring entity namely the Chairman who is at least a third ranking official of the procuring entity and two officers who to the extent possible represent the legal or administrative and finance areas of the procuring entity; and provisional members composed of an officer with technical expertise relevant to the procurement and a representative from end user[1]. Measures to maintain the integrity of the government procurement process are in place. An entity called Government Policy Procurement Board (GPPB) was put up to ensure compliance of government agencies to RA 9184 and its IRR, and assess the effectiveness of the government procurement system. If found wanting, the GPPB can formulate or amend public procurement policies, rules and regulations, update and develop generic procurement manuals and standard bidding forms. It also conducts sustainable training program to develop the capacity of Government procurement officers and employees[3].

To enhance transparency, procurement is standardized with BAC using generic procurement manuals and standard bidding forms; observers including one from non-government organization sit in the bidding process, BAC members follow standard of ethics in dealing with prospective bidders and in handling bid related information and documents; prospective bidders are given equal access to information with the procurement entity establishing internal control on the release of bidding documents; and, bidders are required to disclose that they or any officer of their corporations are not related to the head of the procuring entity[3]. As a form of internal check, a pre-procurement conference is held among BAC members, officials who prepared the bid documents and others involved in the procurement to review relevant documents in relation to their adherence to law. And to ensure that the overriding principle of competition is promoted in the conduct of procurement, the Head of the Agency can reject any and all bids, declare failure of bidding, or not award the contract if it can be established that collusion

occurred which suppresses or tends to suppress competition, where BAC is found to have failed in following the prescribed bidding procedures and where award of the contract will not redound to the benefit of the government. [1][9]

\section{Current Status of Public Procurement in the Philippines}

Refers to R.A. 9184, entitled "An Act Providing for the Modernization, Standardization and Regulation of the Procurement Activities of the Government and for other Purposes," otherwise known as the Government Procurement Reform Act[1]. 
The effective procurement management should be acknowledged complexity, find the right skills \& organize the work, develop a sound strategy, manage timetable effectively, follow sound bid evaluation method and develop a smart, fair contract. Effective procurement requires organized teamwork: authorities, responsibilities, schedule, and resources[11].

It has been repeatedly said that procurement issues and problems are among the reasons for past delays and suspension in government spending. In the 2014 and 2015 reports by the Department of Budget and Management (DBM), procurement is cited as a reason for underspending and this was played up repeatedly in media reports.

From this definition alone, we can see that almost all government spending falls under public procurement and it is logical to assume that whenever the government spends, public procurement data should be produced.

Most of the time, Competitive Bidding which has the following steps:

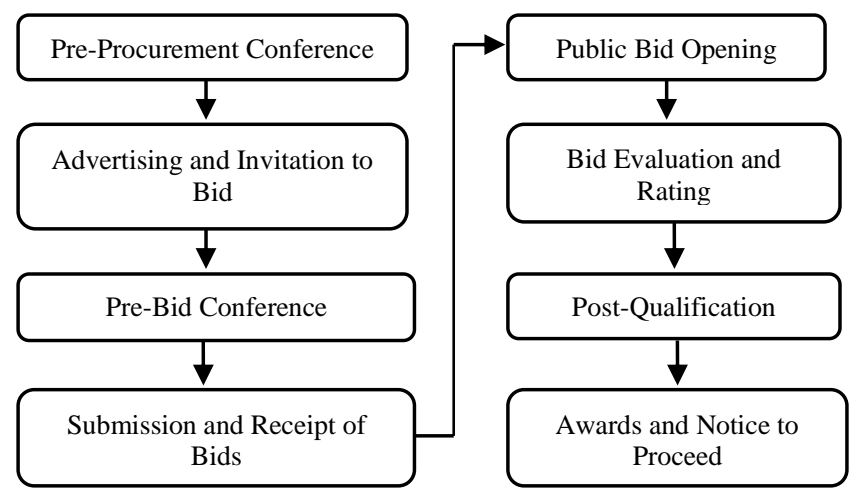

Figure 1: Steps in Public Procurement by Competitive Bidding

Philippine public procurement has a long way to go. The Government Procurement Reform Act and its associated regulations enshrined the appropriate and significant principles of transparency, civil sector involvement and the use of ICTs. However, the promises of this legislation remain largely unmet. For transparency to enable public oversight and change the incentives of internal actors, the data needs to be easily accessible and usable. Procurement information should be available in bulk, machine-readable, open formats.
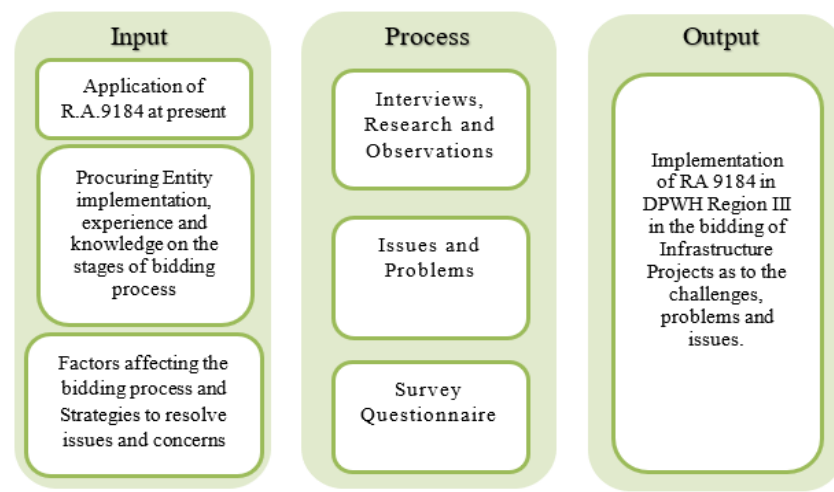

Figure 2: Conceptual Framework of the Study

The R.A. 9184 was envisioned to address the lack of transparency and competition, eliminate collusion and political interference as well as lessen the delays in the procurement process[10]. Implementation experiences by the procuring entity are inputs to identify how well the implementation of the government procurement act based on the challenges and problems and issues encountered. Interviews and researches would finally know what this reform act was achieved. Upon thoroughly study what is being gathered through research and interviews, problems and issues arises are reflected to become this reform at suspicious to any malpractice or unethical activities during the implementation [10].

Evaluating this issues and problems would help determine what is missing in the performance of procuring entity why this loopholes/problems happened and how these problems and challenges could be lessened to pave the way for effective implementation of the Act.

R.A 9184 is vulnerable to any dysfunctional and confusion that may weakened the implementation of the reform act. Knowing the issues and problems affecting the implementation of the reform thru research and interviews, the reform will enhance and evaluated for the improvement of RA9184 in terms of policy and implementation for realizing a good government procurement reform act.

\section{METHODOLOGY}

\section{Research Design}

This chapter presents the research methodology adopted for this study. The researchers employed the descriptive method of research to assess the challenges, problems and issues of the procurement system. 4

To identify challenges and problems and issues of R.A. 9184, a separate open-ended questionnaire and interviews was conducted incorporating challenges identified through literature. The survey questionnaires were personally administered to seven (7) District Engineering Offices of DPWH Region III. The respondents rate the level of understanding in the stages of bidding process of infrastructure projects, the current situation in the implementation of RA 9184, the challenges and problems and issues encountered by the procuring entities and the strategies to resolve such problems encountered during bidding process was collected and analyzed using statistical methods like Weighted Mean.

\section{Research Locale}

From 14 District Engineering Offices of Department of Public Works and Highways in Region III, seven (7) districts will be the respondents of this survey, ( Iba, Castillejos, Orani, Balanga, Lubao, Sindalan, Angeles City. Region III has total land area of 2,215,752 hectares [9]. With the opening of various investment opportunities in Economic Zones in Clarkfield and Subic Bay Area. It is one of the most critical regions in terms of environmental concerns primarily due to the rapid sprawl of industries/establishments and human settlements while the necessary land use and environmental planning are not yet effectively being carved[9]. 


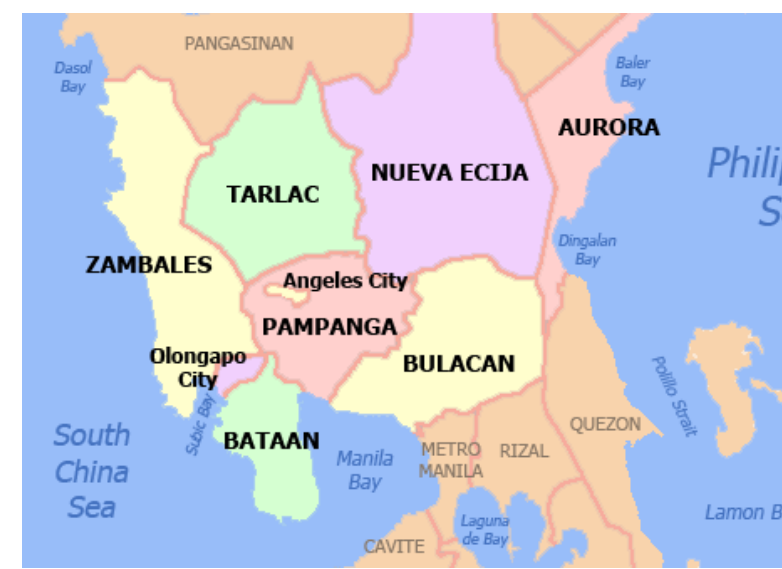

Figure 3: Location Map of Department of Public Works and Highway- Region III District Engineering Offices

\section{Data Gathering and Process Procedure}

Prior to the administration of the questionnaire, the researchers has secured approval permission from the office of the DPWH Region 3 District Engineers of each seven district provinces that has been chosen. After the approval of the request, the researchers personally distributed the questionnaires to the Procurement Division personnel and BAC Committee with the help of the BAC Secretariat to ensure complete retrieval of the questionnaires. They were given a day or two to answer the questionnaire so that they would have time to reflect on the questions and to go over the instrument to ensure completeness, maximum accuracy, consistency and to reduce ambiguity. Analyzing and sorting of completed questionnaires will be taken for testing of results. Respondents were personally interviewed to substantiate the information gathered in the questionnaire.

The motivation of the respondents to answer the questionnaire is the fact that they cannot avoid hence, they might as well use the survey as a means of communicating their issues, concerns, observations and difficulties with the implementation of the procurement process, for a chance that their concerns will be addressed, ( if they have any).

\section{Treatment of Data}

The computation of result of the respondents profile will use the percentage formula and weighted mean. The data gathered from the respondents were treated statistically using the following formulas:

1. Percentage. It was used to determine what proportion of the respondents belong to a specific category based on variables cited .

Formula:

$\%=\mathrm{f} / \mathrm{N} \times 100$

Where:

$$
\begin{aligned}
\% & =\text { percentage } \\
\mathrm{f} & =\text { frequency } \\
\mathrm{N} & =\text {.total number of respondents }
\end{aligned}
$$$$
100=\text { constant value }
$$

2. Weighted Mean. It was used to establish qualitative analysis to show which of the rating scales obtained the highest score.

Formula:

$$
\mathrm{Wx}=(\mathrm{W} \times \mathrm{f}) / \mathrm{x} 100
$$

Where:

$$
\begin{aligned}
& \mathrm{Wx}=\text { weighted mean } \\
& \mathrm{W}=\text { weight of scale } \\
& \mathrm{f}=\text { frequency } \\
& \mathrm{N}=\text { total number of respondents }
\end{aligned}
$$

3. Likert Scale. The Likert Scale was used to quantify the response and for the analysis and interpretation of the computed mean.

All items will be rated by participants on a Likert Scale. Each item will be scaled from 1-4 with the statement.

Table 1: Quantitative Ratings

\begin{tabular}{|c|c|c|c|c|}
\hline Table & $(4)$ & $(3)$ & $(2)$ & $(1)$ \\
\hline 5 & Very Good & Good & Fair & Poor \\
\hline 6 & High & Moderate & Low & None \\
\hline 7 & Strongly Agree & Agree & Disagree & Strongly Disagree \\
\hline 8 & Always & Most of the Time & Rarely & Never \\
\hline 9 & Strongly Agree & Agree & Disagree & Strongly Disagree \\
\hline 10 & Very Important & Important & Less Important & Not important \\
\hline
\end{tabular}

\section{RESULTS AND DISCUSSION}

The focus of this chapter is on the analysis of data gathered from the field with the aid of questionnaires and interviews. Collection of data for this study is centered on Procurement of Infrastructures of the DPWH Region III District Engineering Offices. Out of fourteen concerned district in Region III it was agreed upon by the panel at least half of the district should be administered by the questionnaire provided by the researcher. Since the respondent resides in Zambales province, districts from Zambales ( 1 st District Iba, Zambales; 2nd district Castillejos, Zambales), Bataan ( 1st District Balanga, Bataan; 2nd District Orani, Bataan) and Pampanga ( 1st District Lubao, Pampanga; 2nd District Sindalan , Pampanga; 3rd District Angeles City Pampanga ) are chosen districts. Respondents are BAC members, BAC Secretariat and Technical Working Groups in Procurement Division of Infrastructure projects. This was mainly done to gather information to assess the implementation of Procurement of bidding infrastructure in the country. It was however necessary to consider issues that concerns performance and challenges facing Public Entities in the region.

SECTION 1: Response Rates of Respondent

A total number of seventy-five (75) questionnaires were administered to seven district of DPWH in Region III, composing of BAC members, BAC Secretariat and Technical Working Groups of Procurement division, out of which forty-five (45) were obtained and valid for the data analysis. Ten are invalid and 20 blank questionnaires returned .These valid questionnaires used for the analysis and yielded $60.00 \%$ of response rate as shown in Table 2 . This indicates that, the response rate was quiet average and reflects the views of the entire population.

Table 2: Response Rates

\begin{tabular}{|l|c|c|c|}
\hline & Questionnaire & Responses & Invalid/Returned \\
\hline Respondents & 75 & 45 & 30 \\
\hline Total & $100 \%$ & $60 \%$ & $40 \%$ \\
\hline
\end{tabular}

1.1 Personal Data 
Table 3: Gender Profile of Respondents

\begin{tabular}{|c|c|c|}
\hline & \multicolumn{2}{|c|}{ Gender } \\
\hline Respondents & Male & Female \\
\hline 45 & 29 & 16 \\
\hline $100 \%$ & $64.44 \%$ & $35.56 \%$ \\
\hline
\end{tabular}

Table 3, shows the gender of the respondents sample for the study. Out of the responses obtained from the field, 29 respondents, representing $64.44 \%$ were male, and the remaining 16 respondents, representing $35.56 \%$ were female.Nevertheless, across all the districts of which the sample were taken, were heavily male dominated.

Table 4: Age Profile of Respondents

\begin{tabular}{|l|c|c|c|c|c|}
\hline & \multicolumn{5}{|c|}{ Age } \\
\hline Respondents & $21-30$ & $31-40$ & $41-50$ & $51-60$ & $\begin{array}{c}61 \& \\
\text { above }\end{array}$ \\
\hline 45 & 6 & 9 & 17 & 11 & 2 \\
\hline $100 \%$ & $13.33 \%$ & $20.0 \%$ & $37.78 \%$ & $24.44 \%$ & $4.44 \%$ \\
\hline
\end{tabular}

In terms of ages, Table 4, shows that majority of the respondents belong to age group $41-50$ with $37.78 \%$ and about $4.44 \%$ cover 61 \& above. As to age distribution, majority of the respondents are in the productive years, who can cope up with the stress and tedious process involved in the procurement.

SECTION 2:

Question 2.1: How do you consider your understanding and skills about the following Legal Documents?

Table 5: Ratings for assessment of understanding and competence WEIGHTED MEAN

\begin{tabular}{|c|c|c|c|c|c|c|c|c|}
\hline \multicolumn{9}{|c|}{ WEIGHTED MEAN } \\
\hline Statement & Balanga & Orani & Lubaso & Sindalan & Angeles & Castillejos & $\mathrm{Ibs}$ & TOTAL \\
\hline $\begin{array}{l}\text { a. Pre-Procurement } \\
\text { Conference }\end{array}$ & 3.00 & 2.71 & 3.25 & 3.00 & 3.33 & 3.38 & 3.50 & 3.167 \\
\hline $\begin{array}{l}\text { b. Advertisement } \\
\text { for Comp .Bidding }\end{array}$ & 2.80 & 3.00 & 3.00 & 4.00 & 3.67 & 3.25 & 3.50 & 3.317 \\
\hline $\begin{array}{l}\text { c. Pre-Bid } \\
\text { Conference }\end{array}$ & 3.30 & 2.71 & 3.00 & 4.00 & 3.67 & 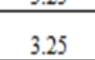 & 3.50 & 3.347 \\
\hline $\begin{array}{l}\text { d. Submission and } \\
\text { Receipt }\end{array}$ & 3.30 & 2.71 & 3.00 & 4.00 & 3.33 & 3.25 & 3.17 & 3.251 \\
\hline $\begin{array}{l}\text { Q. Public Bid } \\
\text { Opening }\end{array}$ & 3.60 & 2.71 & 3.25 & 4.00 & 3.33 & 25 & 3.17 & 3.330 \\
\hline $\begin{array}{l}\text { f. Preliminary } \\
\text { Examination }\end{array}$ & 3.20 & 2.71 & 3.00 & 4.00 & 3.00 & 9.19 & 3.17 & 3.1 \\
\hline $\begin{array}{l}\text { g. Bid Evaluation } \\
\text { And Ranking }\end{array}$ & 3.50 & 2.71 & 3.00 & 4.00 & 3.33 & 3.13 & 3.17 & 3.263 \\
\hline $\begin{array}{l}\text { h. Post- } \\
\text { Qualification }\end{array}$ & 3.50 & 2.71 & 3.25 & 4.00 & 3.67 & 3.13 & 3.17 & 3.347 \\
\hline ard & 3.40 & 2.71 & 3.00 & 4.00 & 3.67 & 3.00 & 2.83 & 3.230 \\
\hline $\begin{array}{l}\text { j. Notice to } \\
\text { Proceed }\end{array}$ & 3.40 & 2.57 & 3.13 & 4.00 & 3.67 & 3.38 & 2.83 & 3.283 \\
\hline
\end{tabular}

Table 5 shows the rating for the assessment of understanding and competence of RA 9184 in the bidding process. These are the stages of bidding process followed by the respondent according to RA 9184. The respondent were asked to identify the level of knowledge and understanding on each stages in implementing bidding process in their own district. It shows that a total mean of 3.347 of respondent indicated a high understanding in the stage of Pre-Bid Conference and Post Qualifications. A total mean of 3.167 of respondents indicated low understanding in the stage of Pre-Procurement Conference. This means attention should be imposed because of the respondent may act the result of misapplication of the law and non-compliance.

Question 2.2: How do you assess the current situation in the implementation of RA 9184 in your agency.
Table 6: Ratings on current situation in the agency

\begin{tabular}{|c|c|c|c|c|c|c|c|}
\hline \\
\hline \multicolumn{8}{|c|}{ 1. Procuring entity are well trained on the entire procur } \\
\hline Balangs & ani & Lubao & Sindalan & Angeles & Castillejos & Iba & TOTAL \\
\hline 3.40 & & & 4.00 & 3.67 & 3.50 & 3.5 & 3.534 \\
\hline \multicolumn{8}{|c|}{$\begin{array}{l}\text { 2. Actual practices of procurement process in our agency are consistent with } \\
\text { written procedures and policies }\end{array}$} \\
\hline Balangg & Orani & o & Sind & Angeles & Castillejos & Iba & TOTAL \\
\hline 3.70 & 29 & 38 & 4.00 & 3.67 & 3.63 & 3.50 & 3.596 \\
\hline \multicolumn{8}{|c|}{$\begin{array}{l}\text { 3. Proper implementation of RA } 9184 \text { laws, rules and regulations from } \\
\text { management to bottom are achieved }\end{array}$} \\
\hline Balangs & Orani & Lubao & Sindalan & Angeles & Castillejos & Iba & TOTAL \\
\hline 3.80 & 3.29 & 3.25 & 3.33 & 3.67 & 3.38 & 3. & 3.389 \\
\hline \multicolumn{8}{|c|}{$\begin{array}{l}\text { 4. The level of procurement competence among government officials within the } \\
\text { procuring entity is constant with their procurement duties and responsibilities }\end{array}$} \\
\hline Balanga & Orani & Lubao & Sindalan & Angeles & Castillejos & Iba & TOTAL \\
\hline 3.40 & 3.00 & 3.13 & 3.33 & 3.67 & 3.38 & 3.00 & 3.273 \\
\hline \multicolumn{8}{|c|}{$\begin{array}{l}\text { 5. Our agency implements measures to identify potential fraud and comption in } \\
\text { the procurement process of infrastructure projects }\end{array}$} \\
\hline Balangg & inl & Lubao & Sindalan & Angeles & Castillejos & Iba & TOTAL \\
\hline 0 & 3.14 & 3.00 & 3. & 3. & 3. & 3.17 & 3. \\
\hline
\end{tabular}

Table 6, shows the current situation in the implementation of RA 9184. With the total mean of 3.596, the respondents indicate a high response to "Actual practices of procurement process in our agency are consistent with written procedures and policies", to the current situation in the implementation of RA9184 in their agency. Followed by " Procuring entity are well trained on the entire procurement process ", with $3.534 \%$. A total mean of 3.273 of the respondents indicate a lowest current situation being practice in their agency which is the ," The level of procurement competence among government officials within the procuring entity is constant with their procurement duties and responsibilities"[7].

Question 2.3: What are the challenges of the procurement entity in the implementation of R.A.9184 particularly in the bidding of infrastructure projects?

Table 7: Ratings on challenges of the procurement entity

\begin{tabular}{|c|c|c|c|c|c|c|c|}
\hline & & & WEIG & ED ME & & & \\
\hline $\begin{array}{l}\text { 1. Mainta } \\
\text { betterpla }\end{array}$ & ing ar & $\begin{array}{l}\text { ccurate } \\
\text { budget }\end{array}$ & $\begin{array}{l}\text { and } u p-t \\
\text { ng }\end{array}$ & date pric & $\mathrm{g}$ inform & of & ials for \\
\hline Balanga & Orani & Lubao & Sindalan & Angeles & Castillejos & Iba & TOTAL \\
\hline 3.80 & 3.00 & 3.13 & 4.00 & 3.00 & 3.13 & 3.33 & 3.341 \\
\hline 2.Verific & tion of & xistence & andidentit & $y$ of the bic & der for eligib & lity & \\
\hline Balanga & Orani & Lubao & Sindalan & Angeles & Castillejos & Iba & TOTAL \\
\hline 3.70 & 3.29 & 3.13 & 3.00 & 3.67 & 3.25 & 3.17 & 3.316 \\
\hline 3.Procur & gentit & n our a & ncy dor & abuset & authority & & \\
\hline Balanga & Orani & Lubao & Sindalan & Angeles & Castillejos & Iba & TOTAL \\
\hline 3.90 & 3.29 & 3.00 & 4.00 & 3.67 & 2.88 & 3.17 & 3.416 \\
\hline 4.Compl & sby & ders & ted imn & iately b & procuri & ntity & \\
\hline Balanga & Orani & Lubao & \begin{tabular}{|l|} 
Sindalan \\
\end{tabular} & \begin{tabular}{|l} 
Angeles \\
\end{tabular} & Castillejos & Iba & TOTAL \\
\hline 3.80 & 3.43 & 3.38 & 4.00 & 3.33 & 3.00 & 3.17 & 3.444 \\
\hline $\begin{array}{l}5 . \mathrm{BAC} d \\
\text { projects }\end{array}$ & & & & , & Ig proc & & tructure \\
\hline Balanga & Orani & Lubao & Sindalan & Angeles & Castillejos & Iba & TOTAL \\
\hline 3.40 & 3.00 & 3.50 & 4.00 & 3.33 & 3.25 & 2.83 & 3.330 \\
\hline $\begin{array}{l}6 . \text { Our } \\
\text { proces }\end{array}$ & & $58 \mathrm{fi}$ & fightin & & & & \\
\hline Balanga & Orani & Lubao & Sindalan & Angeles & Castillejos & Iba & TOTAL \\
\hline 3.40 & 3.00 & 3.50 & 3.33 & 3.67 & 3.00 & 3.00 & 3.271 \\
\hline $\begin{array}{l}\text { 7.Strict } \\
\text { infrastr }\end{array}$ & iplia & $\begin{array}{l}\text { and in } \\
\text { ts }\end{array}$ & lementa & of gui & s to bid & $15 \mathrm{f}$ & \\
\hline Balanga & Orani & Lubao & Sindalan & Angeles & Castillejos & Iba & TOTAL \\
\hline 3.80 & 3.43 & 3.25 & 4.00 & 3.67 & 3.00 & 3.50 & 3.521 \\
\hline
\end{tabular}

Published By: 
Table 7, shows the challenges encountered by the procuring entity. With the responses gathered, a total mean of 3.521 of the respondents strongly agreed that , "Strict compliance and implementation of guidelines to bidding process of infrastructure projects", is one of the challenges that the agency encountered during the procurement followed by the, "Complaints by bidders acted immediately by the procuring entity", with a total mean of 3.444 of respondents. A total mean of 3.271 of respondents indicate the lowest response to, " Our agency is successful in fighting corruption in conducting procurement process under infrastructure projects".

Question 2.4: What is the most vulnerable stage to any protest, problems and issues in the procurement process of infrastructure projects?

Table 8:Ratings on most prone stages to problems and issues

\begin{tabular}{|l|c|c|c|c|c|c|c|c|}
\hline \multicolumn{7}{|c|}{ WEIGHTED MEAN } \\
\hline Statement & Balanga & Orani & Lubao & Sindalan & Angeles & Castillejos & lba & TOTAL \\
\hline $\begin{array}{l}\text { 1. Pre-Procurement } \\
\text { Conference }\end{array}$ & 1.80 & 2.00 & 2.75 & 3.00 & 2.67 & 2.13 & 2.17 & $\mathbf{2 . 3 6 0}$ \\
\hline $\begin{array}{l}\text { 2. Advertisement } \\
\text { for Comp. Bidding }\end{array}$ & 2.10 & 2.43 & 2.88 & 3.33 & 2.67 & 2.50 & 2.17 & $\mathbf{2 . 5 8 3}$ \\
\hline $\begin{array}{l}\text { 3. Pre-Bid } \\
\text { Conference }\end{array}$ & 1.90 & 2.00 & 3.00 & 3.33 & 2.33 & 3.00 & 2.17 & 2.533 \\
\hline $\begin{array}{l}\text { 4. Submission and } \\
\text { Receipt }\end{array}$ & 1.70 & 2.14 & 3.00 & 3.33 & 2.67 & 2.50 & 2.17 & 2.501 \\
\hline $\begin{array}{l}\text { 5. Public Bid } \\
\text { Opening }\end{array}$ & 1.90 & 2.14 & 3.00 & 3.33 & 2.67 & 2.63 & 2.17 & $\mathbf{2 . 5 4 9}$ \\
\hline $\begin{array}{l}\text { 6. Preliminary } \\
\text { Examination }\end{array}$ & 1.90 & 2.14 & 2.25 & 3.33 & 2.67 & 2.88 & 2.17 & 2.477 \\
\hline $\begin{array}{l}\text { 7. Bid Evaluation } \\
\text { And Ranking }\end{array}$ & 1.90 & 2.14 & 2.00 & 3.33 & 2.67 & 2.50 & 2.50 & $\mathbf{2 . 4 3 4}$ \\
\hline $\begin{array}{l}\text { 8.Post- } \\
\text { Qualification }\end{array}$ & 2.30 & 2.29 & 2.00 & 3.33 & 2.67 & 2.63 & 2.17 & 2.484 \\
\hline 9. Notice of Award & 1.70 & 2.29 & 3.00 & 3.33 & 2.67 & 2.63 & 2.17 & 2.541 \\
\hline $\begin{array}{l}\text { 10. Notice to } \\
\text { Proceed }\end{array}$ & 1.70 & 2.29 & 2.00 & 3.33 & 2.67 & 2.63 & 2.50 & 2.446 \\
\hline
\end{tabular}

Table 8, shows the most prone stages that experiencing problems and issues in the bidding process of infrastructure projects. The study sought to find out which stage in the procurement process of infrastructure projects was most susceptible to problems and issues tendencies. Respondents were asked to identify how often they encountered difficulties during implementation .

Finding confirm that a total mean of 2.583 of the respondent indicates, "Advertisement for Competitive Bidding", got the highest rating in most prone stages for problems and issues followed by 2.549 of the respondents indicate, "Public Bidding Opening." A total mean of 2.360 of respondents indicate the least mean of stages indicating ,"Pre-procurement conference" followed "Bid evaluation and Ranking", with a total mean of 2.434 as shown in the table.

Question 2.5: What are the most common problems,

Table 9: Ratings on most common problems and issues

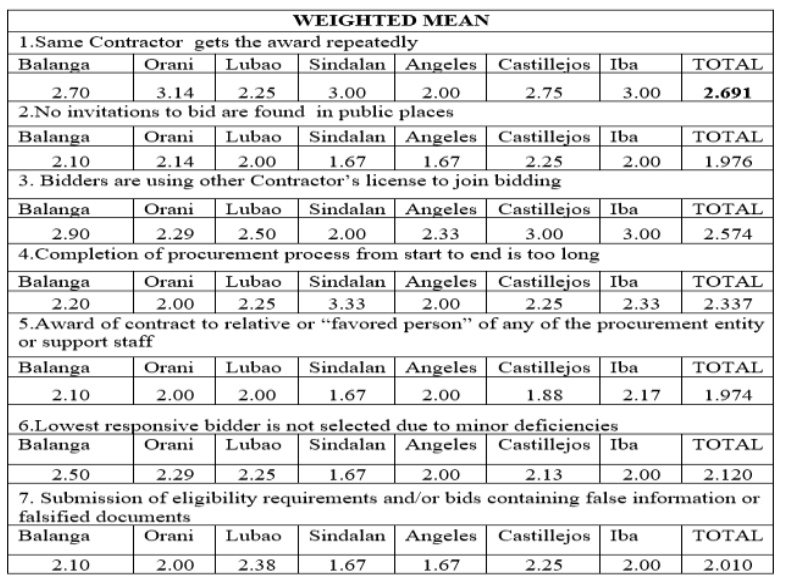

issues and concerns in the bidding of infrastructure projects?

Table 9, shows some potential problems and issues that the procuring entities may encountered. The questionnaire listed seven (7) potential problems and issues in the implementation of bidding process in the infrastructure projects. Each respondent was asked to rate each factor by assigning weights to the extent of agreement or disagreement whether these factors are truly experienced and became problems and issues based on their experienced. The factors were analyzed and ranked.

The rank, weighted mean, was obtained for each factor as shown in the Table 9. The result that emerged from the weighted mean computation revealed of high degree of agreement with weighted mean 2.691 and 2.574 respectively of respondent indicated, "Same Contractor gets the award repeatedly" and 'Bidders are using other Contractor's license to join bidding".

A mean of 1.974 of respondent indicates a low degree of agreement to ," Award of contract to relative or "favored person" of any of the procurement entity or support staff', followed by a 2.010 mean of "Submission of eligibility requirements and/or bids containing false information or falsified documents"[1]. The results show that, there are several problems and issues constraining the implementation of the government procurement Act.

Question 2.6: How important do you think the following factors that can be resolve challenges, problems and issues in procurement process?

Table 10: Ratings on factors that can resolve challenges and problems and issues

\begin{tabular}{|c|c|c|c|c|c|c|c|}
\hline \multicolumn{8}{|c|}{ WEIGHTED MEAN } \\
\hline \multicolumn{8}{|c|}{ 1.Self-discipline/ do not get involved in illegal practice } \\
\hline Balanga & Orani & Lubao & Sindalan & Angeles & Castillejos & Iba & TOTAL \\
\hline 3.80 & 3.00 & 4.00 & 4.00 & 3.33 & 3.75 & 4.00 & .697 \\
\hline \multicolumn{8}{|c|}{ 2.Employees are encourage to report unethical behavior } \\
\hline Balanga & Orani & Lubao & Sindalan & Angeles & Castill & Iba & TOTAL \\
\hline 3.40 & 3.71 & 3.00 & 3.67 & 3.33 & 3. & 3.33 & 3.403 \\
\hline \multicolumn{8}{|c|}{ 3. Implement and identify enough sanctions on erring leaders } \\
\hline Balanga & Orani & Lubao & Sindalan & Angeles & Castillejos & Iba & TOTAL \\
\hline 3.60 & 3.14 & 3.38 & 4.00 & 3.00 & 3.3 & 3.8 & 3.476 \\
\hline \multicolumn{8}{|c|}{ 4.No internal influences (fears, desires, curiosity) } \\
\hline Balanga & Orani & Lubao & Sindalan & Ang & Casti & Iba & TOTAL \\
\hline 3.70 & 3.14 & 3.1 & 4.00 & 3.3 & 3.3 & 3.5 & 3.454 \\
\hline \multicolumn{8}{|c|}{ 5.No political intervention } \\
\hline Balanga & Orani & Lubao & Sindalan & Angeles & \begin{tabular}{|l|} 
Castillejos \\
\end{tabular} & Iba & TOTAL \\
\hline 3.80 & 3.00 & 4.00 & 4.00 & 3.67 & 3.75 & 4.00 & 3.746 \\
\hline
\end{tabular}

Table 10, shows some strategies to resolve or mitigate such problems encountered in the procurement process. Findings confirmed the level of importance of each factors in the implementation of bidding process particularly in the infrastructure project . Respondents shows the highest level of importance to, "No political intervention", with a total mean of 3.746 followed by a a total mean of 3.697 for," Self-discipline/ do not get involved in illegal practice". Less important factor for the respondents indicate a total mean of 3.403 for, "Employees are encourage to report unethical behaviour".

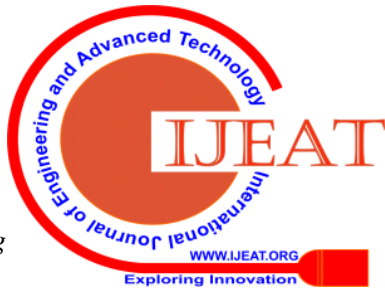


Question 2.8 Are there observed inconsistencies of the procurement process particularly in the infrastructure required by the RA 9184??

Table 11: Respondent's response to observed inconsistencies

\begin{tabular}{|c|c|c|}
\hline Question & Response & Percentage \\
\hline There is/are & 2 & $4.44 \%$ \\
\hline None & 41 & $91.12 \%$ \\
\hline I don't know & 2 & $4.44 \%$ \\
\hline TOTAL & 45 & $100 \%$ \\
\hline
\end{tabular}

Table 11, shows the opinion of the respondents if there any inconsistencies in the procurement process. There are only two (2) respondents with $4.44 \%$, who responded that, "There is/ are", observed inconsistencies in the procurement process particular in the infrastructure projects . Below are their reasons given for such preferences:

1. "Take the case of Makati. If there are no inconsistencies there would be no case against Binay."

2. "No matter how much we adhere to the RA 9184, there will stubborn contractors who is or irresponsible or adversarial and will always have a different perspective or opinion regarding the process."

Out of the 45 respondents, it can be noticed that $4.44 \%$ answered they don't know and $91.12 \%$ answered none. Maybe this is because of the fact that most of the respondents are new to their jobs and they are not yet familiar with both the procurement process".

On further inquiry to the respondents, asking their opinion if they think the implementation of R.A. 9184 particularly in the bidding of infrastructure projects should be amended. Three respondents from different district confirmed that it should be amended.

In order to gather more informative data on how the respondents feel about the implementation of R.A.9184 in their agency, the respondents were asked to write down their suggestion , comments, observation or anything they want to say regarding the procurement process of infrastructure projects in the country. Below is the open-ended questions which itemized the summary of the feedback gathered from the respondents:

Question 2.3 (open-ended question)

What other challenges of procuring entity in the implementation of RA 9184 that you have in your mind that is not being cited above? Below is the list of respondent's own point of view in considering the challenges they experienced.

a. Coordination with LGU and residents. RROW problems

b. There must be a coordination with the local gov't and lot owner regarding RROW

c. During the early stage of the implementation of RA9184 and its IRR LOE encounter some difficulties because of the new rules and regulations, but for thorough seminars from the DBM and DPWH central office they are conducting yearly we became more familiar with the IRR. With new developments face some problems with the contractors.

d.Some contractors used and borrow a license firm for their projects, they don't have their own license firm, they rent construction equipment for their projects, this is one of the challenges we face $n$ the implementation of RA9184

e. One of the challenges is the use of generic name and not the brand name for the procurement equipment. For example in the procurement of service vehicle, the procuring entity cannot specify the brand it will be procuring TOYATA brand for pickup truck rather it can only specify "pickup", 4x2 etc, plus specifications. So it will be disadvantageous if "FOTON" with the same specs win the bidding of lowest calculated bid as embodies under RA 9184. One more is that the lowest bidder of infrastructure projects because of $25 \%$ less of the $A B C$ has a difficulty in finishing the project.

f. New policies, new requirements being implemented abruptly, so as to affect the bidding process such as the need for construction safety and health program (CSHP), when require the submission of contract/NTP prior to approval, which sometimes/or most of the times the contractor couldn't comply on time or change in PHILgeps.

g.The electronics application for eligibility made it possible for every contractor all over the Philippines for the bidding process

h.Competition of contractor

Question 2.4 (open-ended question)

What is the most vulnerable stage to any protest, problems and issues in the procurement process of infrastructure projects? Enumerate if any:

Below are the following problems and issues that the respondent's encountered resulting to hamper the effectivity and perfection of the stages in the bidding process and became most prone stage to issues and concerned.

\#1. Pre-Procurement Conference

- Right of way

- Adherence to law of some documents

- Difference in project title

\#2. Advertisement for Competitive Bidding

- Sometimes advertised wrong project title or there is a correction in project title

- Difference in title ( from listing and advertised title)

- Conflicts on project titles as per POW and SARO sometimes resulting to re-advertisement

\#3. Pre-Bid Conference

- No attendance of bidders

- Attendance of participating bidders

- Less attendees ( contractor)

\#4. Pre-Bid Conference

- Only one envelope for technical and financial component of bid

- When there is no bidder purchase bidding documents

\#5. Public Bid Opening

- eligibility screening

\#6. Preliminary Examination

- Hard to find the required documents due to non-side markings

\#7. Bid Evaluation And Ranking

- contractors dive their bid unrealistically so as to jeopardize the quality of the project.

- lack of required documents

\#8. Post-Qualification

- sometimes in verification of equipment pledge

- Not updated licenses, permit etc

- Expired contractor's license

\#9. Notice of Award

Published By: 
- delayed release of approved construction safety and health program by DOLE which is needed/ requirement in the perfection of contract

\#10. Notice to Proceed

- Simultaneous NTP of contractors cannot proceed because of equipment pledged are not available for simultaneous projects about to start at the same time.

Question 2.5 (open-ended question)

What other common problems, issues and concerns that you have in your mind that is not being cited above? Below are the respondent's own issues and concerned based on their actual experienced.

a. "Same equipment units are used in different projects"

b. "Bid Evaluation section 31.2" there shall be no lower limit of floor on the amount of the award" .... ( quality may suffered)[3].

c. "Buying of Bid documents- Deadline is before the opening of bids. If the contractor is found ineligible in our electronic eligibility process and issue a motion for reconsideration it will delay the bidding process"

d. "Lot owners are not informed regarding the process"

e. "The intervention of both national and local government officials affects the bidding of various infra projects"

f. "intervention of local government officials"

g. "political intervention"

h. "The common problem is that under R.A 9184, the winner should be the lowest among the bidders. But sometimes the lowest is more than $20 \%$ lower than the ABC. The problem will be in the implementation of the project site"

i. "Maybe the culture, contractors from Zambales are quite different compare with those other province or region in terms of competitiveness, mind-set and likes"

j. "No matter have needs your address to the RA 9184, there will always be a findings from COA"

k. "Trainings/seminars for procurement staff must be regularly done for updating and /or enhancement of knowledge in procurement.

Question 2.7 Are there any additional factors you think are important in resolving any problems and issues regarding procurement of infrastructures? If so, please enumerate:

a. "There must be a separate room for BAC-TWG room for assesses bidding documents"

b. "BAC Composition- at least third ranking permanent employee ( district office); These are section chief or higher( too busy)",

c. "Advertisement - posting at least in a newspaper of gen circulation, Philgeps, agency and office premises ( too many posting)"

d. "Shorten the bidding process"

e. "All prospective bidders must always conduct project site inspection prior to their preparation and submission of their detailed estimates and bid cost to avoid any further request of the winning bidder a change order or variation order when the awarded project is being implemented"

f. "Transparency by adding more observer from the civil society groups , Non-government organization, people's organization and watchdogs of the bidding process. Conduct more training on individuals who manage the bidding process. On-line bidding should be implemented to all government entity to lessen connivance among contractors"

g. "A change from the top will redound to the bottom. The top management should exemplify the role model so as to have credence in everything the management would like to show or seemed to be"

h. "The inclusion of civil society/NGO is a more to make the bidding more transparent. What if the whole bidding process is being conducted by separate commissioned entry"

i. "prospective bidders should always be fair and competitive"

j. "More frequent seminars and trainings for BAC members, secretariat and TWG with workshop"

k. "cooperation among members is the key factor for the success of bidding process".

\section{SUMMARY}

The descriptive method of research was utilized in this study with the questionnaire as the instrument in the collection of data. There are 45 respondents in this study. Among the respondents were BAC members, BAC Secretariat and Technical Working Groups of Procurement Division under DPWH Region III of seven district engineering offices namely:

1. 1st District Engineering Office, Orani, Bataan

2. 2nd District Engineering Office, Balanga, Bataan

3. 1st District Engineering Office, Iba, Zambales

4. 2nd District Engineering Office, Castillejos, Zambales

5. 1st District Engineering Office, Sindalan, Pampanga

6. 2nd District Engineering Office, Lubao, Pampanga

7. 3rd District Engineering Office, Angeles, Pampanga

The data collected were treated statistically using percentage and weighted mean.

The findings indicated a high level of knowledge and understanding in the areas of Pre-Bid conference and Post Qualification. Areas indicated low and need of attention include Pre procurement conference.

Procuring entities are very much strict with the compliance of the Act ensuring the fairness and transparency. Here are some respondents point of view base on their experiences in the bidding process of RA 9184 in the infrastructure projects:

1. To determine the responsive bid, bid must be substantially complies with the request for proposal and prescribed requirements.

2. Minor deficiencies in the preparation and submission of bid documents considered to ineligibility because of the items that is missing in the inclusion of the documents Some bidders submitting multiple bidders to meet winning bid.

3. Experiencing collusive bidders by contractors.

\section{CONCLUSION AND RECOMMENDATIONS}

\section{Conclusion}

All respondent shows level of awareness and understanding in the implementation of R.A 9184 of bidding process and they are able to review and re-evaluated all concerns pertaining to any ambiguity of the process. Respondent show competence on how far they understand and implement the process properly. The study concluded that procurement activities are being disturbed by interferences from powerful external influences. 


\section{Recommendations}

1. More frequent seminars and trainings with workshop to enhance capability to understand more deeper the implementation of each stages on the bidding process.

2. The Department of Public Works and Highways are now ready for Standard Organization ISO 9001 certification for standardization. Electronics eligibility screening are being implemented to assure updated profile and eligibility of the bidders and capability to acquire projects. To ensure-real time transactions in government procurement, electronics bidding process particularly in the infrastructure projects is recommended to avoid and prevent connivance of the bidders and stop political intervention. The consequences of this will be a tremendous reduction in paper work.

3. Recommendation to shorten the bidding process. It will be a great help to all procuring entity to shorten the days to complete the entire procuring process to establish the project as soon as possible. It will be more reliable if the days/duration of each stages/process will be compress so that it will lessen for the bidders to have unnecessary or unbehavioral action like, diving the cost, to win the project.

4. Review the bid form with all potential bidders so there is no mistakes on bid day. This eliminates challenges from a procuring entity. Identifying minor irregularities to major irregularities should be recognize to eliminate confusion in selecting the winning bid and also to save the government money in selecting the lowest responsive bidder.

\section{REFERENCES}

1. R.A. 9184 (Government Procurement Reform Act) https://www.gppb.gov.ph/laws/laws/RA_9184.pdf

2. The 2016 Revised Implementing Rules and Regulations of RA 9184. https://www.gppb.gov.ph/laws/laws/RevisedIRR.RA9184.pdf

3. The Government Procurement Policy Board. https://www.gppb.gov.ph/

4. The Philippine Government Electronic Procurement System. https://www.philgeps.gov.ph/

5. Ng'ang;a, Samuel, Impact of E-Procurement on the Operational Performance in the Ministry of Energy and Petroleum in Kenya, D61/68194/2011, page 5

6. Mbae, Lawrence Njeru, Public Procurement Performance of County Governments in Kenya, D61/79069/2012, page10

7. Nyeko, Sonny nd Kakwezi, Patrick, procurement Processes and Performance: Efficiency and Effectiveness of the Procurement Function, Department of Public Works, Queensland Government, 2006., page 6.

8. Civil Works - Department of Public Works and Highways. http://www.dpwh.gov.ph/dpwh/business/procurement/civil_works/aw arded_contracts

9. Policy Board, Senate Economic Plan, August2008, https://www.senate.gov.ph/publications/PB\%202008-05\%20-\%20Plu gging\%20the\%20Loopholes.pdf

10. D.K.,Makabira, Role of Procurement Practices on the Performance of Corporate Organizations in Kenya, (Eduardo, Talero,2004), p371

11. Public Contracting in the Philippines: Breakthroughs and Barriers. Philippine Center for Investigative Journalism (PCIJ) with support from Hivos and Article 19 http://pcij.org/wp-content/uploads/2018/01/PCIJ.-Open-Contracting-i n-Philippines-Report_01102018_b.pdf

12. Public Procurement Data in the Philippines and Where to Find It: https://schoolofdata.org/2019/03/06/public-procurement-data-in-the-p hilippines-and-where-to-find-it

13. Transparency Case Study: Public Procurement in the Philippines by Alexander Furnas; https://sunlightfoundation.com/2013/10/07/case-study-public-procure ment-in-the-philippines/

\section{AUTHORS PROFILE}

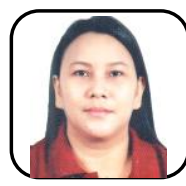

Vivian E. Gutierrez is a graduate of Masters of Engineering Management major in Construction Management (MEM-CM) at Pamantasan ng Lungsod ng Maynila (PLM) and currently pursuing her Doctor of Philosophy in Engineering Management (PhD. EnM) at Nueva Ecija University of Science and Technology (NEUST). She is a Licensed Civil Engineer, Registered Master Plumber and Industrial Engineering graduate. She is currently a member of Physical Plant Team of Columban College, Inc. Member of Philippine Institute of Civil Engineers (PICE) and National Master Plumbers Association of the Philippines, Inc (NAMPAP). Her research works focuses on engineering materials, project development management and technology application in construction field.

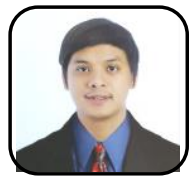

Rex Mervin P. Ramos is a graduate of M.S. in Engineering Management from the Mapua University in 2017 and currently pursuing his Doctor of Philosophy in Engineering Management (PhD. EnM) at Nueva Ecija University of Science and Technology (NEUST). He finished his bachelor's degree in Electronics and Communications Engineering from the Mapua Institute of Technology in 2011. He is a registered Electronics Engineer duly licensed by the Professional Regulation Commission (PRC) of the Republic of the Philippines. He is a regular member of the Institute of Electronics Engineers of the Philippines (IECEP). He has 7 years of work experience in broadcast communications technology and currently work as Supervising Data Analyst / Network Administrator in a government organization. He is a regular resource speaker of student's activities from various colleges and universities.

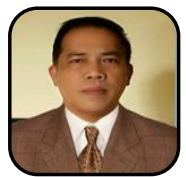

Noel T. Florencondia. is a graduate of Doctor of Philosophy in Engineering Management (PhD. EnM) at Nueva Ecija University of Science and Technology (NEUST). He is a Professional Electrical Engineer and member of Institute of Integrated Electrical Engineers. He is currently the Dean of the College of Engineering of Nueva Ecija University of Science and Technology (NEUST). His field of research focuses on Electrica system Design, High Rise Building Designs and Arc Flashes

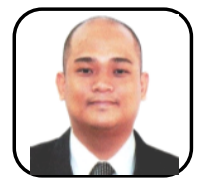

Ryan John L. De Lara is a Licensed Electronics Engineer, Accredited Broadcaster, Certified Cable Test Technician and Six Sigma Black Belt Certified. He is currently the Director for Research Development and Productivity Office and the former Dean of the College of Engineering and Computer Technology of Wesleyan University - Philippines Cushman Campus. He finished both his Masters and Doctor of Philosophy in Engineering Management at Nueva Ecija University of Science and Technology. The interim governor of the Institute of Electronics Engineers of the Philippines Nueva Ecija Chapter (Accreditation No. 37). His research interest ranges from electronics system design, microcontroller application, energy system optimization, prototype development and electronics waste (e-waste) management. 